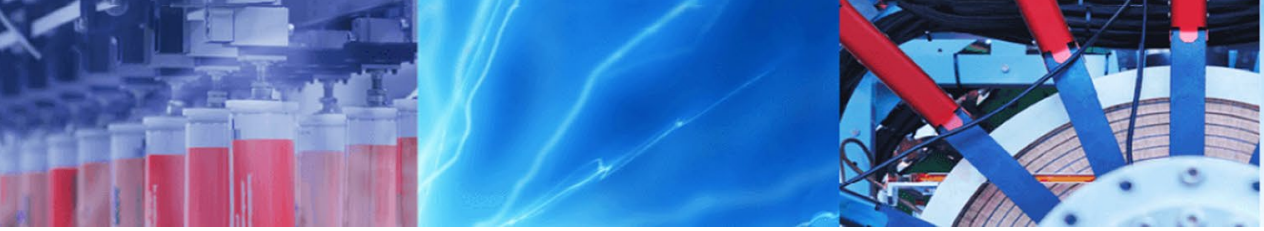

Research Article

\title{
Efficiency of Eichhornia crassipes in the treatment of raw kitchen wastewater
}

\author{
Rijwana Parwin $^{1} \cdot$ Kakoli Karar Paul ${ }^{1}$
}

(c) Springer Nature Switzerland AG 2019

\begin{abstract}
The present water crisis mandates the reuse of wastewater for non-potable purpose. In this study, raw kitchen wastewater (KWW) was treated using Eichhornia crassipes, as a low-cost and eco-friendly remediation method. The advantage of Eichhornia crassipes is quick and high efficiency for removal of pollutants from wastewater. It was found that during characterization of raw $\mathrm{KWW}$, the value of $\mathrm{pH}$ and the concentration of nitrate nitrogen and ammonium nitrogen were exceeding the permissible limit for irrigation water quality. A field experiment was conducted for 21 days, and the physicochemical parameters were monitored at 3 days of interval. After treatment, the concentration of nitrate nitrogen and ammonium nitrogen reduced to $97.79 \%$ and $92.03 \%$, respectively, within 15 days, whereas the pH value increased from 4.3 to 6.67. It was found that Eichhornia crassipes showed good reduction efficiency for $\mathrm{BOD}_{5}(77.23 \%)$, ammonium nitrogen $(92.03 \%)$, total organic carbon (39.24\%) and total suspended solids (95.94\%) as compared to control (KWW sample without Eichhornia crassipes). An increase of 50\% biomass of Eichhornia crassipes was observed at the end of the experiment. The study found that the treated KWW can be reused for irrigation purpose as it satisfied irrigation standard guidelines.
\end{abstract}

Keywords Eichhornia crassipes · Irrigation · Kitchen wastewater · Phytoremediation

\section{Introduction}

Water is the most precious resource to prolong life on earth. Plessis [1] stated that out of the total available water resource, only $3 \%$ is freshwater, and approximately $69 \%$ of it is locked up in glaciers. Due to rapid urbanization, industrialization and growth in population, the availability of freshwater resource now become a critical issue. In future, the water demand for irrigation for a populated country like India will be 910 billion cubic metres (BCM) by 2025 and rise to 1072 BCM by 2050 [2]. Thus, it is the high time to think not only about the judicious use of existing water resource but also for the reuse of wastewater for non-potable purposes.

Domestic wastewater generates from household activities are mainly of two types: grey water (excluding toilet wastewater) and blackwater (including toilet wastewater) [3]. The grey water contributes $80 \%$ of total domestic wastewater, and $44 \%$ of grey water is produced from the kitchen outlet from an Indian household [4]. Kitchen wastewater (KWW) is produced on an average of $12 \mathrm{~L}$ per person per day (LPD) in the residential area in India [5], rural school 4 LPD [6], and Indian cities (Delhi, Kolkata, Mumbai, Hyderabad, Ahmadabad, Kanpur and Madurai) 14.92 LPD [7]. KWW has the potential to combat the water crisis for non-potable use. A suitable treatment method is required for the treatment of KWW.

Different types of plants have been used across the globe for KWW treatment. Phragmites australis was used in a constructed wetland, which is made up of half brick, gravel and sand layers for KWW treatment. The author suggested that this is helpful in reducing organic matter

Rijwana Parwin, rijwana.parwin27@gmail.com; Kakoli Karar Paul, k_karar1@yahoo.co.in | ${ }^{1}$ Department of Civil Engineering, NIT, Rourkela 769008, India.

SN Applied Sciences (2019) 1:381 | https://doi.org/10.1007/s42452-019-0400-0

Received: 2 January 2019 / Accepted: 23 March 2019 / Published online: 30 March 2019 
present in KWW [8]. Plant species like Phragmites australis, Phragmites karka and Ipomoea aquatica were used for KWW treatment in a constructed wetland made up of gravels. This treated grey water can be reused for gardening or toilet flushing [9]. Vetiver grass (Chrysopogon zizanioides) was planted in a drum filled with soil for KWW treatment. The treated wastewater can be reused for domestic and irrigation purposes [10]. Water lettuce (Pistia stratiotes) was planted on a constructed wetland made up of gravel, sand and humus layer. This wetland is helpful in reducing the concentration of an organic and inorganic constituent of wastewater. The treated effluent is suitable for non-drinking purposes like crop irrigation and keeping aquatic animals [11]. Eichhornia crassipes (EC) was used for KWW treatment in a constructed wetland made up of gravel, sand and humus layer. Treated effluent can be used for non-drinking purposes like crop irrigations and fishing [12]. The pores of the upper layer of the substrate will be clogged by tiny particles present in KWW. Therefore, proper maintenance is required at a certain interval of time. In our earlier study, EC was used for 8 days for treatment of KWW, but this is not focused on more retention period [13].

The performance of $\mathrm{EC}$ was also evaluated for domestic wastewater collected from stabilized pond [14-16], raw sewage from municipal wastewater treatment plant [17, 18], synthetic medium and groundwater [19], sewage from the aerated lagoon [20], raw wastewater from fish farm [21], dye wastewater [22], oily river water [23], domestic wastewater [24], dairy wastewater [25] and river water [26].

KWW is away from toilet contamination and has less concentration of heavy metals [5]. But the presence of oil and grease, nutrients (nitrate, ammonia), trace elements in KWW plays a significant contribution to pollute water bodies [27-29]. Stagnant KWW become a place of breeding environment for insect pests and release ammonia [30]. Proper low-cost treatment of KWW will contribute significantly towards the conservation of freshwater [9]. According to Panda et al. [31] from the available freshwater, $85 \%$ is used for irrigation purpose. The use of treated KWW in irrigation will be beneficial for reducing the present water stress. Sivarajah and Gnanavelrajah [32] grew leafy vegetables Ipomoea aquatica and Alternanthera sessilis (excellent sources of carotene, folate, niacin, iron, vitamin $C$ and calcium) using KWW (except detergents wash water). Growing plants using KWW solve problems of wastewater disposal and water scarcity. Abegunrin et al. [33] reported that the use of untreated KWW for the irrigation of cucumbers did not adversely affect the soil. Domestic wastewater applied for irrigation had no significant effects apart from slight changes in salt solubility and alkalinity on clay soil [34]. The present research work investigates the effectiveness of EC in raw KWW without aeration, without substrate layer, and without dilution in bench-scale field experimental set-up.

\section{Methodology}

\subsection{Field experimental set-up}

In this study, raw KWW samples were collected from the hostel of National Institute of Technology Rourkela, India $\left(22.2525^{\circ} \mathrm{N}, 84.9046^{\circ} \mathrm{E}\right)$. The collected KWW samples looked whitish with an oily smell and enriched with tiny food particles. For field experimental set-up, three plastic containers, each of 30-litre capacity were considered. Two containers $\left(E C_{1}\right.$ and $\left.E C_{2}\right)$ were kept with $\mathrm{KWW}$ sample with $\mathrm{EC}$ for the treatment. One container was filled with only KWW sample referred as a control to observe the natural degradation. $\mathrm{EC}_{1}, \mathrm{EC}_{2}$ and control were kept in an open environment for 21 days and monitored at 3 days of interval. Before starting of the field experiments, healthy EC plants were collected from nearby ponds and washed carefully using tap water to remove dead plant parts. After that, these plants were kept in tap water for acclimatization. The details of the plant's characteristics used for the experiment are shown in Table 1. The number of green leaves per plant was made by the visual count, while the leaf surface area was estimated using Blanco and Folegatti equation [35].

\subsection{Analysis techniques}

For the characterization of KWW, the physical and chemical parameters like $\mathrm{pH}$, nitrate nitrogen, ammonium nitrogen, oil and grease, dissolved oxygen (DO), biochemical oxygen demand $\left(\mathrm{BOD}_{5}\right)$, total organic carbon (TOC), total suspended solids (TSSs) and total dissolved solids (TDSs) were evaluated for both raw and treated KWW samples. The list of standard followed, methods and instruments used for KWW characterization are summarized in Table 2. The measurement of $\mathrm{pH}, \mathrm{DO}$, and ammonium nitrogen was performed using HQ40D HACH meter. The nutrient nitrate nitrogen and

Table 1 Morphological characteristics of the plant at initial set-up

\begin{tabular}{lll}
\hline Parameters & $\mathrm{EC}_{1}$ & $\mathrm{EC}_{2}$ \\
\hline No. of plants & 15 & 15 \\
No. of leaves/plant & $4.67 \pm 0.620$ & $4.6 \pm 0.910$ \\
Surface area of leaves $\left(\mathrm{cm}^{2}\right) /$ plant & $39.49 \pm 10.790$ & $34.31 \pm 8.730$ \\
Longest root $(\mathrm{cm}) /$ plant & $12.07 \pm 1.580$ & $11.60 \pm 3.830$ \\
Fresh plant weight $(\mathrm{g})$ & 813 & 780 \\
\hline
\end{tabular}

Mean \pm standard deviation 
Table 2 Experimental procedure for characterization of KWW sample

\begin{tabular}{|c|c|c|c|}
\hline Physicochemical parameters & Standards adopted & Methods used for estimation & Instrument used for estimation \\
\hline Colour & - & - & Eye observation \\
\hline Odour & - & - & Olfactory sense \\
\hline $\mathrm{pH}$ & - & - & HQ40D HACH \\
\hline $\mathrm{DO}(\mathrm{mg} / \mathrm{L})$ & - & - & HQ40D HACH \\
\hline $\mathrm{BOD}_{5}(\mathrm{mg} / \mathrm{L})$ & IS: 3025 Part 44 [40] & Dilution technique & BOD incubator REICO \\
\hline TDS, TSS (mg/L) & IS: 3025 Part $16 \& 17[37,38]$ & Gravimetric method & Hot air oven REICO \\
\hline Nitrate nitrogen (mg/L) & - & - & DR/890:8039 HACH \\
\hline Ammonium nitrogen (mg/L) & - & - & HQ40D HACH \\
\hline Oil and grease (mg/L) & IS: 3025 Part 39 [39] & Partition gravimetric method & Separating funnel \\
\hline Total organic carbon (mg/L) & - & - & DR/890:10129 HACH \\
\hline
\end{tabular}

TOC were measured by DR/890:8039 and DR/890:10129 $\mathrm{HACH}$, respectively. The mean value of $\mathrm{pH}$ was calculated by mathematical transformation to hydrogen ion concentration and averaged it and then reconverted to $\mathrm{pH}$ [36]. The TDS and TSS were measured by the gravimetric method using Indian Standard IS: 3025 part 16 [37] and IS: 3025 part 17 [38], respectively. The oil and grease were measured by partition gravimetric method

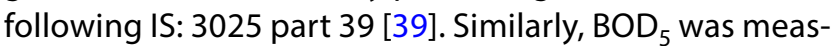
ured by dilution technique following IS: 3025 part 44 [40]. Each test was conducted three times to minimize errors. The initial characterization of raw KWW sample in control, $\mathrm{EC}_{1}$ and $\mathrm{EC}_{2}$ is shown in Table 3 . The obtained results were compared with the National Indian Standard IS: 2490 Part I [41] and International standards Food and Agriculture Organization (FAO) [42]. Further, the results of a field experiment were compared with related existing literature. The result obtained from the natural degradation of KWW (control) and phytoremediation using $\mathrm{EC}\left(\mathrm{EC}_{1}\right.$ and $\left.\mathrm{EC}_{2}\right)$ were compared through an analysis of variance (single-factor ANOVA) for a $95 \%$ confidence interval.

\section{Results and discussion}

The study was carried out to evaluate the nutrient uptake capability of EC from raw KWW. This study also identified the effect of raw KWW on EC biomass. The field observation during 3 days of interval is mentioned in Table 4. Initially, the collected sample was whitish. After 12 days, the colour change was noticed in all the containers. Sample colour turned into blackish green in control due to the development of algae, whereas light brown colour was observed in $\mathrm{EC}_{1}$ and $\mathrm{EC}_{2}$ as the plant root started decaying. Dead plant leaves were manually separated from the plants. Similarly, the scum layer formed on wastewater surface and stuck on plant roots was manually removed. On day 9 , new leaves were first observed in $\mathrm{EC}_{2}$ container. After completion of the experiment on day 21, larvae were detected in control. During field experiment, evaporation loss for control was approximately $0.68 \mathrm{~L}$ per day, whereas for $\mathrm{EC}_{1}$ and $\mathrm{EC}_{2}$ evapotranspiration loss was nearly $0.88 \mathrm{~L}$ per day and $0.90 \mathrm{~L}$ per day, respectively. The results obtained from
Table 3 KWW sample characterization at the starting of the field experiment

\begin{tabular}{|c|c|c|c|}
\hline Physicochemical parameters & Control & $\mathrm{EC}_{1}$ & $\mathrm{EC}_{2}$ \\
\hline Colour & Whitish & Whitish & Whitish \\
\hline Odour & Oily smell & Oily smell & Oily smell \\
\hline $\mathrm{pH}$ & $4.32 \pm 0.02$ & $4.30 \pm 0.02$ & $4.31 \pm 0.01$ \\
\hline $\mathrm{DO}(\mathrm{mg} / \mathrm{L})$ & $0.97 \pm 0.06$ & $1.00 \pm 0.10$ & $0.97 \pm 0.15$ \\
\hline $\mathrm{BOD}_{5}(\mathrm{mg} / \mathrm{L})$ & $1166.67 \pm 30.55$ & $953.33 \pm 23.09$ & $926.67 \pm 11.55$ \\
\hline TSS (mg/L) & $1143.33 \pm 3.06$ & $1397.33 \pm 1.15$ & 838.00 \\
\hline TDS (mg/L) & $1000.67 \pm 3.06$ & $874.67 \pm 1.15$ & $965.33 \pm 3.06$ \\
\hline Nitrate nitrogen $(\mathrm{mg} / \mathrm{L})$ & $161.70 \pm 3.64$ & $144.90 \pm 2.10$ & $143.50 \pm 1.21$ \\
\hline Ammonium nitrogen $(\mathrm{mg} / \mathrm{L})$ & $54.93 \pm 0.55$ & $49.37 \pm 0.15$ & $50.50 \pm 0.30$ \\
\hline Oil and grease (mg/L) & $338.33 \pm 0.29$ & 338.50 & 338.50 \\
\hline Total organic carbon (mg/L) & 114.40 & 114.40 & 114.40 \\
\hline
\end{tabular}

Mean \pm standard deviation, $n=3$ 
Table 4 Field observation during the experiment

\begin{tabular}{|c|c|c|c|c|c|c|c|c|}
\hline & $\begin{array}{l}\text { Initial condi- } \\
\text { tion }\end{array}$ & 3rd day & 6th day & 9th day & 12th day & 15th day & 18th day & 21st day \\
\hline \multicolumn{9}{|l|}{ Colour } \\
\hline Control & Whitish & No change & No change & No change & Blackish green & Blackish green & Blackish green & Black \\
\hline $\mathrm{EC}_{1}$ & Whitish & No change & No change & No change & $\begin{array}{l}\text { Slightly brown } \\
\text { colour }\end{array}$ & Brown colour & $\begin{array}{l}\text { Deep brown } \\
\text { colour }\end{array}$ & $\begin{array}{l}\text { Deep brown } \\
\text { colour }\end{array}$ \\
\hline $\mathrm{EC}_{2}$ & Whitish & No change & No change & No change & $\begin{array}{l}\text { Slightly brown } \\
\text { colour }\end{array}$ & $\begin{array}{l}\text { Slightly brown } \\
\text { colour }\end{array}$ & $\begin{array}{l}\text { Light brown } \\
\text { colour }\end{array}$ & $\begin{array}{l}\text { Deep brown } \\
\text { colour }\end{array}$ \\
\hline \multicolumn{9}{|l|}{ Odour } \\
\hline Control & Oily smell & $\begin{array}{l}\text { Fermented } \\
\text { rice }\end{array}$ & $\begin{array}{l}\text { Fermented } \\
\text { rice }\end{array}$ & $\begin{array}{l}\text { Fermented } \\
\text { rice }\end{array}$ & Severe & Severe & Slightly & Slightly \\
\hline $\mathrm{EC}_{1}$ & Oily smell & $\begin{array}{l}\text { Fermented } \\
\text { rice }\end{array}$ & Slightly & Slightly & Slightly & Slightly & No smell & No smell \\
\hline $\mathrm{EC}_{2}$ & Oily smell & $\begin{array}{l}\text { Fermented } \\
\text { rice }\end{array}$ & Slightly & Slightly & Slightly & Slightly & No smell & No smell \\
\hline \multicolumn{9}{|l|}{ Leaves } \\
\hline Control & - & - & - & - & - & - & - & - \\
\hline $\mathrm{EC}_{1}$ & Green & No change & $\begin{array}{l}\text { Started } \\
\text { browning }\end{array}$ & $\begin{array}{l}\text { Started } \\
\text { browning }\end{array}$ & $\begin{array}{l}\text { New } \\
\text { leaves + old } \\
\text { brown } \\
\text { leaves }\end{array}$ & New leaves & Healthy leaves & Healthy leaves \\
\hline $\mathrm{EC}_{2}$ & Green & No change & $\begin{array}{l}\text { Started } \\
\text { browning }\end{array}$ & $\begin{array}{l}\text { New } \\
\text { leaves + old } \\
\text { brown } \\
\text { leaves }\end{array}$ & $\begin{array}{l}\text { New } \\
\text { leaves + old } \\
\text { brown } \\
\text { leaves }\end{array}$ & New leaves & Healthy leaves & Healthy leaves \\
\hline \multicolumn{9}{|c|}{ Insect larva } \\
\hline Control & No & - & - & - & - & - & - & Yes \\
\hline $\mathrm{EC}_{1}$ & No & - & - & - & - & - & - & - \\
\hline $\mathrm{EC}_{2}$ & No & - & - & - & - & - & - & - \\
\hline \multicolumn{9}{|c|}{ Scum layer } \\
\hline Control & No & Yes on surface & Yes on surface & Yes on surface & Yes on surface & Yes on surface & Yes on surface & Thin layer \\
\hline $\mathrm{EC}_{1}$ & No & Surface \& root & Surface \& root & Surface \& root & Surface & Surface & - & - \\
\hline $\mathrm{EC}_{2}$ & No & Surface \& root & Surface \& root & Surface \& root & Surface & Surface & - & - \\
\hline
\end{tabular}

ANOVA at alpha $=0.05$ showed that there was a statistical significance to the result of ammonium nitrogen leading to reject the null hypothesis as $F$-value was higher than $\mathrm{F}$ critical, and the $p$ value was less than alpha level.

In Fig. 1, after day 9, it was observed that the $\mathrm{pH}$ value from 4.9 to 6.84 increased nonlinearly and formed an $\mathrm{S}$-shaped curve for control, whereas the $\mathrm{pH}$ value for $\mathrm{EC}_{1}$ and $\mathrm{EC}_{2}$ increased linearly. Thus, EC has a gradual effect on $\mathrm{pH}$ increment. This may be due to the photosynthetic activity of $\mathrm{EC}$. The dissolved $\mathrm{CO}_{2}$ present in $\mathrm{KWW}$ sample decreased during photosynthesis; as a result, $\mathrm{pH}$ value increased. Rezania et al. [16] observed an increase in $\mathrm{pH}$ (13\%) value during the treatment of domestic wastewater using EC. Akinbile and Yusoff [21] observed that by aeration, the $\mathrm{pH}$ reduction rate was higher in phytoremediation with EC. Gopal [43] found that for optimum growth condition of EC, $\mathrm{pH}$ should range within 6-8. For better microbial activities, the optimum $\mathrm{pH}$ values for the nitrification process may vary from 6.6 to 8.0 [16]. A similar study was conducted by Seun et al. [12] and observed an increase of $60.5 \% \mathrm{pH}$ value during 10 days of the experiment. Different plants used for KWW treatment, in existing literature, are compared in Table 5.

Fruit and vegetables like legumes, cauliflower, spinach, green peas, etc. are the sources of nitrogen, amino acid, and protein. Initially, organic nitrogen is converted to ammonia nitrogen by anaerobic process called ammonification, then ammonia nitrogen is converted to nitrate nitrogen by aerobic process called nitrification and finally, nitrate nitrogen is converted to nitrogen gas in a low-oxygen (anoxic) environment, and the process is known as denitrification [44]. In control, nitrate nitrogen concentration reduced from 161.7 to $10.30 \mathrm{mg} / \mathrm{L}(93.63 \%)$ after 3 days. $E C_{1}$ and $E C_{2}$ showed almost the same percentage reduction (92\%) after 3 days. Although control showed good response over EC, but EC did not add any nutrient 
Fig. 1 Effect of Eichhornia crassipes on different parameters of KWW at a different time interval. a $\mathrm{pH}, \mathbf{b}$ nitrate nitrogen, $\mathbf{c}$ ammonium nitrogen and d dissolved oxygen (DO)

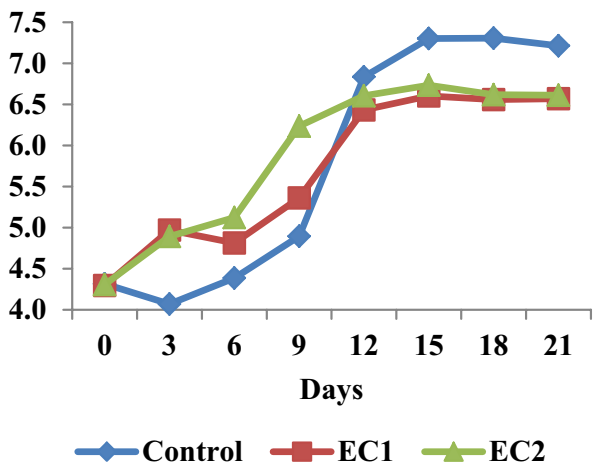

(a)

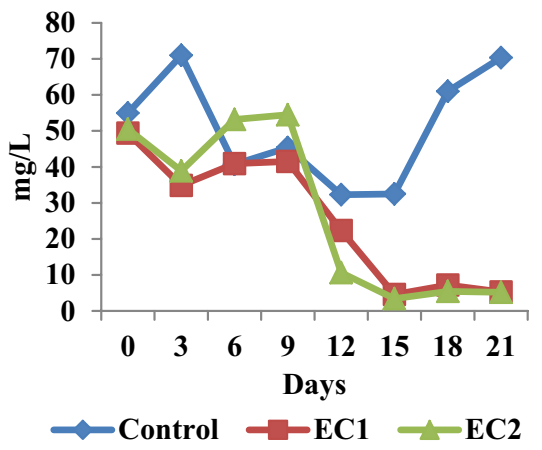

(c)

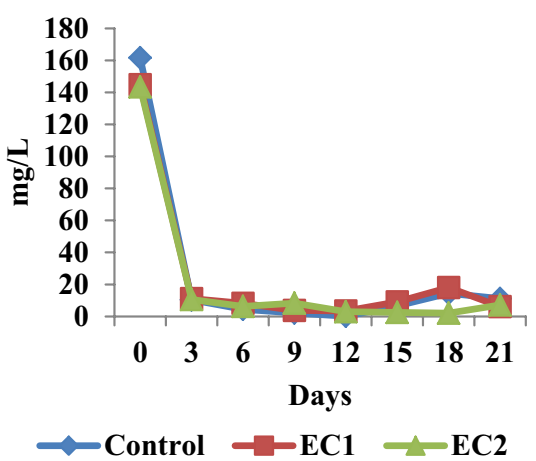

(b)

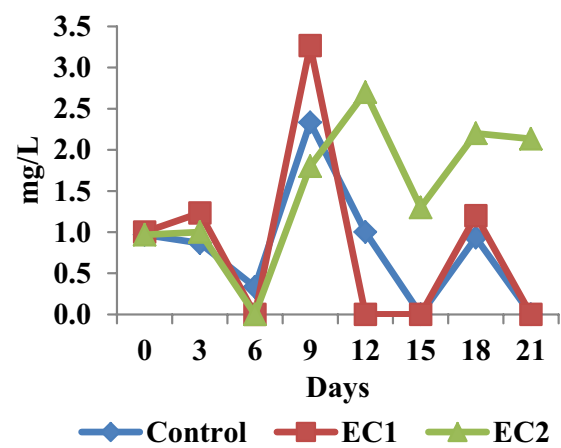

(d)

Table 5 Comparison of result obtained by phytoremediation (EC mean) with related existing literature on KWW treatment

\begin{tabular}{|c|c|c|c|c|c|c|c|}
\hline Parameters & Baskar et al. [8] & $\begin{array}{l}\text { Mathew et al. } \\
\text { [10] }\end{array}$ & $\begin{array}{l}\text { Oladejo et al. } \\
\text { [11] }\end{array}$ & Seun et al. [12] & $\begin{array}{l}\text { Gupta and Nath } \\
\text { [9] }\end{array}$ & $\begin{array}{l}\text { Parwin and Paul } \\
\text { [13] }\end{array}$ & Present study \\
\hline Duration & 7 days & 30 days & 10 days & 10 days & 1 day & 8 days & 21 days \\
\hline Plants used & $\begin{array}{l}\text { Common reed } \\
\text { (Phragmites } \\
\text { australis) }\end{array}$ & $\begin{array}{l}\text { Vetiver grass } \\
\text { (Chrysopogon } \\
\text { zizanioides) }\end{array}$ & $\begin{array}{l}\text { Water lettuce } \\
\text { (Pistia strati- } \\
\text { otes) }\end{array}$ & $\begin{array}{l}\text { Water hyacinth } \\
\text { (Eichhornia } \\
\text { crassipes) }\end{array}$ & $\begin{array}{l}\text { Ipomoea } \\
\text { aquatica }\end{array}$ & $\begin{array}{l}\text { Eichhornia cras- } \\
\text { sipes }\end{array}$ & $\begin{array}{r}\text { Eichhornia } \\
\text { crassipes }\end{array}$ \\
\hline $\mathrm{pH}$ & - & $43.85 \% *$ & $23 \% *$ & $60.5 \% *$ & $50.13 \% *$ & $6.08 \% *$ & $55.01 \% *$ \\
\hline $\begin{array}{l}\text { Nitrate nitrogen } \\
(\mathrm{mg} / \mathrm{L})\end{array}$ & - & - & $50 \%$ & $66.7 \%$ & - & $78.75 \%$ & $97.79 \%$ \\
\hline $\begin{array}{l}\text { Ammonium } \\
\text { nitrogen } \\
(\mathrm{mg} / \mathrm{L})\end{array}$ & - & - & - & - & - & $60.28 \%$ & 92.03 \\
\hline $\mathrm{BOD}_{5}(\mathrm{mg} / \mathrm{L})$ & $75 \%$ & $83.15 \%$ & $83.43 \%$ & - & - & - & $77.23 \%$ \\
\hline $\mathrm{DO}$ (mg/L) & - & $400 \% *$ & $58 \%$ & $77.5 \%$ & - & $33.33 \%$ & $157.63 \% *$ \\
\hline TOC (mg/L) & - & - & - & - & - & $15.38 \%$ & $39.24 \%$ \\
\hline TSS (mg/L) & $41 \%$ & - & - & - & - & - & $95.94 \%$ \\
\hline TDS (mg/L) & $4 \%$ & - & - & - & $58.58 \%$ & $69.97 \%$ & $76.17 \%$ \\
\hline $\begin{array}{l}\text { Oil and grease } \\
(\mathrm{mg} / \mathrm{L})\end{array}$ & - & - & - & - & - & - & $99.33 \%$ \\
\hline
\end{tabular}

*Percentage increase

to sample. Ayyasamy et al. [19] found nitrate concentration reduced to $64 \%$ in a synthetic medium containing $100 \mathrm{mg} / \mathrm{L}$ of nitrate and observed that at higher concentration, reduction efficiency decreases due to osmotic pressure. Seun et al. [12] observed a reduction of $66.7 \%$ nitrate during 10 days of the experiment.

As shown in Fig. 1, in control ammonium nitrogen concentration decreased from initial 54.93 to $32.30 \mathrm{mg} / \mathrm{L}$ 
(41.20\%) in 12 days, and after that, it gradually increased. $\mathrm{EC}_{1}$ and $\mathrm{EC}_{2}$ showed ammonium nitrogen reduction efficiency of $90.81 \%$ and $93.24 \%$, respectively, in 15 days. Parwin and Paul [13] observed good reduction efficiency (60.28\%) in ammonium nitrogen while treating raw KWW using EC for 8 days. Rezania et al. [16] found reduction efficiency of $95 \%$ for ammonium nitrogen, $92 \%$ for $\mathrm{BOD}_{5}$, $78 \%$ for chemical oxygen demand and $62 \%$ for TSS during treatment of domestic wastewater using EC. Ismail et al. [20] reported that $\mathrm{EC}$ reduced the ammonium nitrogen concentration (72\%) from domestic wastewater.

It was observed that in 9 days, the $\mathrm{DO}$ of control and $\mathrm{EC}_{1}$ increased to $141.38 \%$ and $226.67 \%$, respectively (Fig. 1). Akinbile and Yusoff [21] reported that for wastewater treated using EC with aeration, the value of DO increased to $36.55 \%$ within the first 3 weeks of the experiment. In a study conducted by Rezania et al. [16], 23\% increase of DO level was observed in 14 days of experiment. Aerobic micro-organisms need oxygen for the degradation of organic matter present in raw KWW, thus reducing the oxygen concentration in the sample. Dense plant cover on water surface reduces atmospheric oxygen diffusion. The floating plants play a vital role in transferring atmospheric oxygen $(30 \%-40 \%)$ to rhizosphere through aerenchyma (internal gas space) for aerobic microbial activity [18].

$\mathrm{BOD}_{5}$ removal was recorded $62.28 \%$ for control, whereas $76.92 \%$ for $E C_{1}$ and $77.55 \%$ for $E_{2}$ in 6 days (Fig. 2). Similarly, Costa et al. [45] observed a reduction of $50 \% \mathrm{BOD}_{5}$ in a hydraulic retention period of 20 days from piggery wastewater using EC. Kumari and Tripathi [17] reported that a mixed culture of EC and Salvinia natans was effective for removal of $84.5 \%$ of $\mathrm{BOD}_{5}$ and $26.6 \%$ of nitrate
Fig. 2 Effect of Eichhornia crassipes on the reduction in physicochemical parameters of KWW at a different time interval. a $\mathrm{BOD}_{5}, \mathbf{b} \mathrm{TOC}, \mathbf{c}$ TSS, d TDS and $\mathbf{e}$ oil and grease

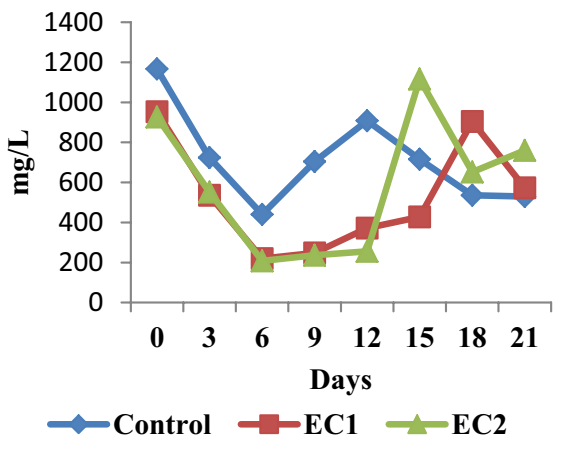

(a)

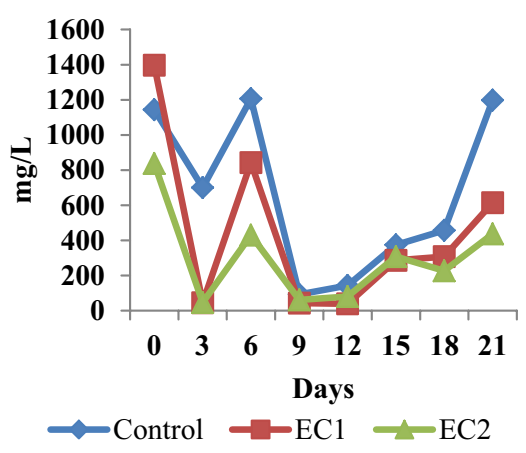

(c)

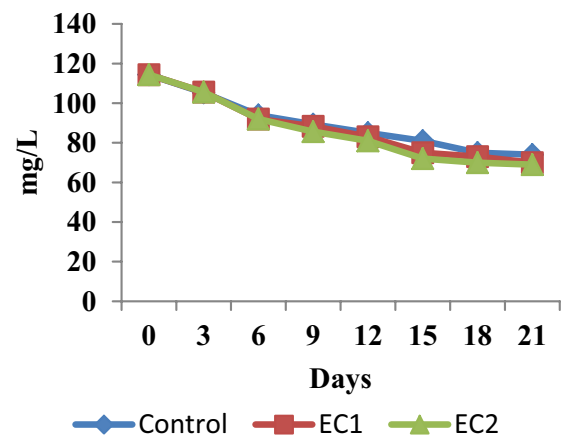

(b)

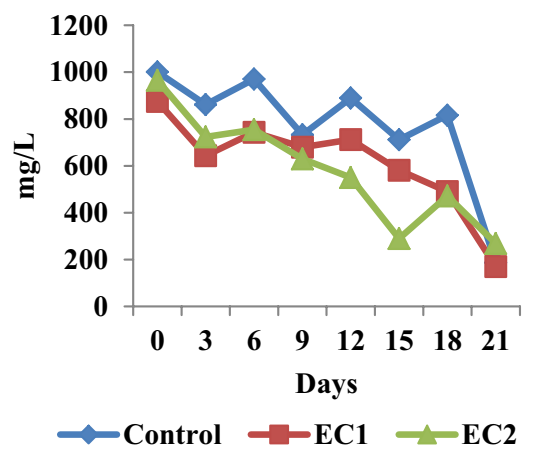

(d)

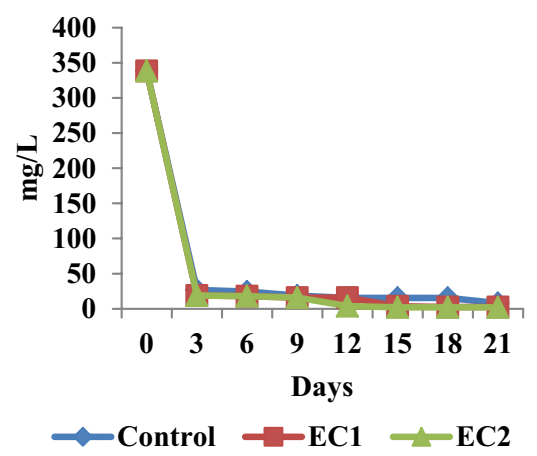

(e) 
nitrogen in municipal wastewater. Plant root system acts as proper media for microbial growth providing an oxygenic condition in the rhizosphere for microbial degradation of organic pollutants [16, 46]. Similarly, Shah et al. [22] indicated that the treatment performance of EC in $25 \%$ dye wastewater dilution was $42 \%$ for $\mathrm{BOD}_{5}$.

In Fig. 2, TOC showed a good reduction of $38.81 \%$ for $\mathrm{EC}_{1}$ and $39.68 \%$ for $\mathrm{EC}_{2}$, whereas $35.31 \%$ for control in 21 days. In a study conducted by Parwin and Paul [13] after 8 days of the retention time, the removal efficiency of TOC was $15.38 \%$ and $13.67 \%$ for EC and control, respectively. Rezania et al. [15] found a $45 \%$ reduction of TOC in 12 days of the experiment.

TSS results showed significant reduction of $91.89 \%$ for control in 9 days, whereas $\mathrm{EC}_{1}$ and $\mathrm{EC}_{2}$ showed a $97.23 \%$ (in 12 days) and $94.51 \%$ (in 3 days), respectively (Fig. 2). Loan et al. [24] indicated that treatment efficiency of EC was $53.3 \%$ for TSS, $53.4 \%$ for chemical oxygen demand, $61.4 \%$ for phosphate phosphorous and $32.6 \%$ for ammonium nitrogen after 21 days. Valipour et al. [18] showed that the reduction efficiency of EC was $73.02 \%$ for TSS, $79 \%$ for chemical oxygen demand and $86.42 \%$ for $\mathrm{BOD}_{5}$ at a hydraulic retention time of $14 \mathrm{~h}$. Kim et al. [14] and Valipour et al. [18] stated that while suspended solids try to pass through the plant roots, it can be trapped and become metabolized by micro-organisms as the roots of floating plants act as support for microbial growth, or it eventually settled due to the force of gravity.

A higher value of TDS present in raw KWW may be due to the washing of plates and utensils that contain the food waste stuck into it. TDS removal for control (81.34\%), EC (80.56\%) and $\mathrm{EC}_{2}$ (72.20\%) was observed in 21 days. A study by Munavalli and Saler [25] reported that EC had no significant effect on reducing TDS in dairy wastewater. As reported by Rezania et al. [16], 11\% removal efficiency for TDS was found for treating domestic wastewater using EC. However, a reduction of $26 \%$ for TDS was reported by Moyo et al. [26] during the treatment of polluted river water using EC. Similarly, Parwin and Paul [13] observed $67.72 \%$ and $69.97 \%$ reduction in TDS in control and EC, respectively.

KWW especially from educational, professional organizations and restaurants is rich in oil and grease. Oil layer on the surface of water obstructs the evaporation loss but simultaneously prevents entry/exit of oxygen from the water surface. As per the observation, the oil reduction was almost the same in both control and EC. This is due to the formation of scum layer on the water surface of control and root zone and water surface of KWW treated with EC. During the experiment, the scum layer was manually removed from the surface and root zone for entry/exit of oxygen from the water surface. It is observed that the oil layer stuck on roots of plants prevents nutrient uptake from KWW. Hence, plant roots were washed with tap water at 3 days interval. Lopes and Piedade [23] observed that a lower dose of oil ( $<3 \mathrm{~mL} / \mathrm{L})$ did not cause significant alteration in morphology and biomass of EC plants.

During KWW treatment, the growth efficiency is based on increasing weight of biomass of EC from initial zero (0) day to last day (21st) of the experiment. It was observed that the growth in biomass obtained was $1185 \mathrm{~g} \mathrm{(51.92 \% )}$ on day 21 for $\mathrm{EC}_{2}$, which is more in biomass when compared to $E C_{1}(48.21 \%)$. A similar study was conducted by Rezania et al. [15], and Dixit et al. [47] found an increase in biomass weight of $46 \%$ and $45 \%$, respectively.

The obtained results of control and EC were compared with IS: 2490 Part I [41] and FAO [42] in Table 6. The pH

Table 6 Comparison of obtained results with National and International standards

\begin{tabular}{|c|c|c|c|c|c|c|}
\hline Parameters & Control & $\mathrm{EC}_{1}$ & $\mathrm{EC}_{2}$ & $\begin{array}{l}\text { Irrigation permis- } \\
\text { sible limit (FAO) } \\
{[42]}\end{array}$ & $\begin{array}{l}\text { On land for irriga- } \\
\text { tion (IS: } 2490, \text { Part } \\
\text { I) }[41]\end{array}$ & $\begin{array}{l}\text { Public sewer (IS: } \\
\text { 2490, Part I) [41] }\end{array}$ \\
\hline $\mathrm{pH}$ & $\begin{array}{l}6.84, \\
\text { (12th day) }\end{array}$ & $\begin{array}{l}6.43 \\
\text { (12th day) }\end{array}$ & $\begin{array}{l}6.24 \\
\text { (9th day) }\end{array}$ & $6-8.5$ & $5.5-9$ & $5.5-9$ \\
\hline $\mathrm{BOD}_{5}(\mathrm{mg} / \mathrm{L})$ & $\begin{array}{l}\text { 440.00, } \\
\text { (6th day) }\end{array}$ & $\begin{array}{l}220.00 \\
\text { (6th day) }\end{array}$ & $\begin{array}{l}\text { 208.00, } \\
\text { (6th day) }\end{array}$ & - & 100 & 350 \\
\hline TSS (mg/L) & $\begin{array}{l}\text { 92.67, } \\
\text { (9th day) }\end{array}$ & $\begin{array}{l}44.67 \\
\text { (3rd day) }\end{array}$ & $\begin{array}{l}46.00 \\
\text { (3rd day) }\end{array}$ & - & 200 & 600 \\
\hline TDS (mg/L) & $\begin{array}{l}1000.67 \\
\text { (1st day) }\end{array}$ & $\begin{array}{l}874.67 \\
\text { (1st day) }\end{array}$ & $\begin{array}{l}965.33 \\
\text { (1st day) }\end{array}$ & 2000 & 2100 & 2100 \\
\hline Oil and grease (mg/L) & $\begin{array}{l}\text { 18.83, } \\
\text { ( } 9 \text { th day) \& 8.00, } \\
\text { (21st day) }\end{array}$ & $\begin{array}{l}\text { 19.00, } \\
\text { (3rd day) \& 3.50, } \\
\text { (15th day) }\end{array}$ & $\begin{array}{l}\text { 19.00, } \\
\text { (3rd day) \& 3.83, } \\
\text { (12th day) }\end{array}$ & - & 10 & 20 \\
\hline Nitrate nitrogen $(\mathrm{mg} / \mathrm{L})$ & $\begin{array}{l}4.43 \\
\text { (6th day) }\end{array}$ & $\begin{array}{l}8.17 \\
\text { (6th day) }\end{array}$ & $\begin{array}{l}6.23 \\
\text { (6th day) }\end{array}$ & 10 & - & - \\
\hline $\begin{array}{l}\text { Ammonium nitrogen } \\
(\mathrm{mg} / \mathrm{L})\end{array}$ & $\begin{array}{l}\text { 32.30, } \\
\text { (12th day) }\end{array}$ & $\begin{array}{l}\text { 4.54, } \\
\text { (15th day) }\end{array}$ & $\begin{array}{l}3.41, \\
\text { (15th day) }\end{array}$ & 5 & - & - \\
\hline
\end{tabular}


value for both control and EC was found to be suitable for irrigation use after 12 days of the experiment. According to the standard FAO [42] for both control and EC, the nitrate nitrogen concentration was suitable for irrigation use after 6 days. Treated $\mathrm{KWW}$ of $\mathrm{EC}_{1}$ and $\mathrm{EC}_{2}$ satisfied the ammonium nitrogen limit for irrigation after 15 days. There is no such standard limit for $\mathrm{DO}, \mathrm{BOD}_{5}, \mathrm{TSS}$, oil and grease and TOC in FAO [42]. While comparing with TSS limit of irrigation standard IS: 2490 part 1 [41], on an average both control and EC were found to be suitable for irrigation use after day 9 and day 3, respectively. The initial TDS concentration was within the limit of IS: 2490 Part I [41] and FAO [42].

\section{Conclusion}

The study aims to evaluate the pollutants' removal efficiency of EC for raw KWW. Physicochemical parameters like $\mathrm{pH}$, ammonium nitrogen, nitrate nitrogen, $\mathrm{DO}, \mathrm{BOD}_{5}, \mathrm{TOC}$, TSS, TDS, and oil and grease were monitored in 3 days of interval for 21 days of the experiment. KWW sample without EC was considered as control. Both EC and control were kept in the same environment for the same observation period. The reduction efficiency of EC showed significant results as compared to control for $\mathrm{BOD}_{5}$, ammonium nitrogen, TOC and TSS. However, the reduction in TDS and nitrate nitrogen was observed slightly more in control compared to EC. The treated KWW samples satisfied the irrigation standard of water quality. It is recommended for further heavy metal characterization of raw KWW.

Acknowledgements This study is a part of Ph.D. work. The authors would like to express their sincere gratitude and thanks to staff members of Environmental Engineering Laboratory of Civil Engineering Department of National Institute of Technology, Rourkela, for their help and assistance during laboratory analysis.

\section{Compliance with ethical standards}

Conflict of interest The authors declare that they have no conflict of interest.

\section{References}

1. Plessis AD (2017) Global water availability, distribution and use. Freshwater challenges of South Africa and its Upper Vaal River. Springer, New York, pp 3-11. https://doi.org/10.1007/978-3-31949502-6

2. CWC (2010) Water and related statistics. Water Planning and Project Wing Central Water Commission, India

3. Beler-Baykal B (2015) Stream segregation in household use: a review of grey water as an alternative source of water and yellow water as an alternative source of fertilizers. Water Qual Expo Health 7:27-37. https://doi.org/10.1007/s12403-013-0105-3

4. Vakil KA, Sharma MK, Bhatia A, Kazmi AA, Sarkar S (2014) Characterization of greywater in an Indian middle-class household and investigation of physicochemical treatment using electrocoagulation. Sep Purif Technol 130:160-166. https://doi.org/10.1016/j. seppur.2014.04.018

5. Edwin GA, Gopalsamy P, Muthu N (2014) Characterization of domestic gray water from point source to determine the potential for urban residential reuse: a short review. Appl Water Sci 4:39-49. https://doi.org/10.1007/s13201-013-0128-8

6. NEERI (2007) Guidance manual grey water reuse in rural Schools. National Environmental Engineering Research Institute, India

7. Shaban A, Sharma RN (2007) Water consumption pattern in domestic households in major Indian Cities. Econ Polit Wkly 42(23):2190-2197

8. Baskar G, Deeptha VT, Rahman AA (2009) Treatment of wastewater from kitchen in an institution hostel mess using constructed wetland. Int J Recent Trends Eng 1(6):54-58

9. Gupta A, Nath JR (2018) Kitchen greywater treatment in a constructed wetland microcosm using aquatic macrophytes. Water Qual Manag. Water Science and Technology Library. https://doi. org/10.1007/978-981-10-5795-3-13

10. Mathew M, Rosary SC, Sebastian M, Cherian SM (2016) Effectiveness of vetiver system for the treatment of wastewater from an institutional kitchen. Procedia Technol 24:203-209. https://doi. org/10.1016/j.protcy.2016.05.028

11. Oladejo OS, Ojo OM, Akinpelu OI, Adeyemo OA, Adekunle AM (2015) Wastewater treatment using constructed wetland with Water lettuce (Pistia stratiotes). Int J Chem Environ Biol Sci 3(2):119-124

12. Seun OO, Adeshina ON, Kolawole K, Adedeji TS, Jamal A (2015) Kitchen wastewater treatment with constructed wetland using water hyacinth. Int J Sci Eng Res 6(1):834-840

13. Parwin R, Paul KK (2018) Treatment of kitchen wastewater using Eichhornia crassipes. In: E3S Web of conferences, vol 34, p 02033. https://doi.org/10.1051/e3sconf/20183402033

14. Kim Y, Giokas DL, Chung PG, Lee DR (2003) Design of water hyacinth ponds for removing algal particles from waste stabilization ponds. Water Sci Technol 48:115-123

15. Rezania S, Ponraj M, Din MFM, Chelliapan S, Sairan FM (2016) Effectiveness of Eichhornia crassipes in nutrient removal from domestic wastewater based on its optimal growth rate. Desalin Water Treat 57(1):360-365. https://doi.org/10.1080/19443 994.2014.967305

16. Rezania S, Din MFM, Taib SM, Dahalan FA, Songip AR, Singh L, Kamyab H (2016) The efficient role of aquatic plant (water hyacinth) in treating domestic wastewater in continuous system. Int J Phytorem 18(7):679-685. https://doi.org/10.1080/15226 514.2015.1130018

17. Kumari M, Tripathi BD (2014) Effect of aeration and mixed culture of Eichhornia crassipes and salvinia natans on removal of wastewater pollutants. Ecol Eng 62:48-53

18. Valipour A, Raman VK, Ahn YH (2015) Effectiveness of domestic wastewater treatment using a bio-hedge water hyacinth wetland system. Water 7:329-347. https://doi.org/10.3390/w7010 329

19. Ayyasamy PM, Rajakumar S, Sathishkumar M, Swaminathan K, Shanthi K, Lakshmanaperumalsamy P, Lee S (2009) Nitrate removal from synthetic medium and groundwater with aquatic macrophytes. Desalination 242:286-296. https://doi. org/10.1016/j.desal.2008.05.008

20. Ismail Z, Othman SZ, Law KH, Sulaiman AH, Hashim R (2015) Comparative performance of Water hyacinth (Eichhornia crassipes) and Water lettuce (Pista stratiotes) in preventing 
nutrients build-up in municipal wastewater. CLEAN Soil Air Water 43(4):521-531

21. Akinbile CO, Yusoff MS (2012) Assessing water hyacinth (Eichhornia crassipes) and lettuce (Pistia stratiotes) effectiveness in aquaculture wastewater treatment. Int J Phytorem 14(3):201-211

22. Shah RA, Kumawat DM, Singh N, Wani KA (2010) Water hyacinth (Eichhornia Crassipes) as a remediation tool for dye-effluent pollution. Int J Sci Nat 1(2):172-178

23. Lopes A, Piedade MTF (2014) Experimental study on the survival of the water hyacinth (Eichhornia crassipes (Mart.) Solms-Pontederiaceae) under different oil doses and times of exposure. Environ Sci Pollut Res 21:13503-13511

24. Loan NT, Nguyen PM, Anh NTN (2014) The role of aquatic plants and microorganisms in domestic wastewater treatment. Environ Eng Manag J 13(8):2031-2038

25. Munavalli GR, Saler PS (2009) Treatment of dairy wastewater by water hyacinth. Water Sci Technol 5(4):713-722

26. Moyo P, Chapungu L, Mudzengi B (2013) Effectiveness of water Hyacinth (Eichhornia crassipes) in remediating polluted water: the case of Shagashe River in Masvingo, Zimbabwe. Adv Appl Sci Res 4(4):55-62

27. Promya J, Siripen T, Richard D (2008) Phytoremediation of kitchen wastewater by Spirulina platensis (Nordstedt) Geiteler: pigment content, production variable cost and nutritional value. Mj Int J Sci Technol 2(1):159-171

28. Chandekar N, Godboley BJ (2017) A review on phytoremediation a sustainable solution for treatment of kitchen wastewater. Int J Sci Res (IJSR) 6(2):1850-1855

29. Katam K, Bhattacharyya D (2018) Comparative study on treatment of kitchen wastewater using a mixed microalgal culture and an aerobic bacterial culture: kinetic evaluation and FAME analysis. Environ Sci Pollut Res. https://doi.org/10.1007/s1135 6-018-2209-6

30. Mohamed RMSR, Chan CM, Ghani HB, Azarudin M, Yasin M, Kassim AHM (2013) Application of peat filter media in treating kitchen wastewater. Int J Zero Waste Gener 1(1):11-16

31. Panda KG, Kumar N, Hossain A (2017) Conceptual view of lowcost sensory Evaporimeter based on Internet of Things (loT). In: 11 th international conference on intelligent systems and control (ISCO), IEEE, pp 363-367

32. Sivarajah S, Gnanavelrajah N (2015) Potential to grow selected leafy vegetables in kitchen wastewater hydroponics. AmEurasian J Agric Environ Sci 15(12):2337-2342. https://doi. org/10.5829/idosi.aejaes.2015.15.12.12798

33. Abegunrin TP, Awe GO, Idowu DO, Onigbogi OO, Onofua OE (2013) Effect of kitchen wastewater irrigation on soil properties and growth of cucumber (Cucumis sativus). J Soil Sci Environ Manag 4(7):139-145. https://doi.org/10.5897/jssem2013.0412
34. Singh PK, Deshbhratar PB, Ramteke DS (2012) Effects of sewage wastewater irrigation on soil properties, crop yield and environment. Agric Water Manag 103:100-104

35. Blanco FF, Folegatti MV (2003) A new method for estimating the leaf area index of cucumber and tomato plants. Hortic Bras 21(4):666-669

36. Kuna-Broniowska I, Smal H (2017) Statistical measures of the central tendency for $\mathrm{H}^{+}$activity and $\mathrm{pH}$. Soil Sci Ann 68(4):174181. https://doi.org/10.1515/ssa-2017-0022

37. IS: 3025 (part 16) Reaffirmed (2002) Methods of sampling and test (physical and chemical) for water and wastewater, filterable residue (total dissolved solids). Bureau of Indian Standards, Manak Bhavan, 9 Bahadur Shah Zafar Marg, New Delhi

38. IS: 3025 (part 17) Reaffirmed (2002) Methods of sampling and test (physical and chemical) for water and wastewater, non-filterable residue (total suspended solids). Bureau of Indian Standards, Manak Bhavan, 9 Bahadur Shah Zafar Marg, New Delhi

39. IS: 3025 (part 39) Reaffirmed (2003) Methods of sampling and test (physical and chemical) for water and wastewater, oil and grease. Bureau of Indian Standards, Manak Bhavan, 9 Bahadur Shah Zafar Marg, New Delhi

40. IS: 3025 (part 44) Reaffirmed (2003) Methods of sampling and test (physical and chemical) for water and wastewater, biochemical oxygen demand (BOD). Bureau of Indian Standards, Manak Bhavan, 9 Bahadur Shah Zafar Marg, New Delhi

41. IS: 2490 (part 1) 1981. Tolerance limits for industrial effluents

42. FAO (1994) Water quality for agriculture, irrigation and drainage paper 29, M-56

43. Gopal B (1987) Aquatic plant studies 1, water hyacinth. Elsevier, Oxford, $p 471$

44. APHA (2012) Standard methods for the examination of water and wastewater, 22nd edn. American Public Health Association, Washington (DC)

45. Costa RHR, Bavaresco ASL, Medri W, Philippi LS (2000) Tertiary treatment of piggery wastes in water hyacinth ponds. Water Sci Technol 42(10):211-214

46. Vymazal J (2007) Removal of nutrients in various types of constructed wetlands. Sci Total Environ 380:48-65

47. Dixit A, Dixit S, Goswami CS (2011) Process and plants for wastewater remediation: a review. Sci Rev Chem Commun 11:71-77

Publisher's Note Springer Nature remains neutral with regard to jurisdictional claims in published maps and institutional affiliations. 